\title{
THE INTERDEPENDENCE OF COMPUTER AND COMMUNICATIONS SERVICES AND FACILITIES: A QUESTION OF FEDERAC REGULATION
}

\author{
Delbert D. Smith $\dagger$
}

\section{INTRODUCTION}

Technological development has created an interdependence between data processing services and communication networks. Many separate computer customers may be linked to a central data bank or messageswitching control through existing communication facilities. On the other hand, communications common carriers presently use computers to provide new services by means of circuit and message switching. Numerous and sophisticated interconnections between computer and communication services and facilities have raised problems of regulatory policy that are aggravated by the anomaly of partial regulation: communications carriers are regulated under the Communications Act of $1934,{ }^{1}$ but computer services remain thus far unregulated.

In late 1966, the Federal Communications Commission announced an inquiry to determine "under what circumstances data processing, computer information and message switching services, or any particular combination thereof-whether engaged in by established common carriers or other entities-are or should be subject to the provisions of the Communications Act." ${ }^{2}$ This article examines the major issues raised by the FCC notice of inquiry and discusses the alternatives available to the Commission within the context of the relevant legislation.

$\dagger$ Legal Advisor, Space Science \& Engineering Center, University of Wisconsin. B.S. 1963, M.S. 1965, J.D. 1969, University of Wisconsin. Ph.D. 1968, Cambridge University. Member, Wisconsin Bar.

147 U.S.C. $\$ \$ 151-609$ (1964 \& Supp. III, 1968) [hereinafter cited as Communications Act].

2 In re Regulatory and Policy Problems Presented by the Interdependence of Computer and Communication Services and Facilities, FCC Notice of Inquiry, FCC 64-1004, Dkt. No. 16,979, 31 Fed. Reg. 14,752, 14,754 (1966). Of special concern to the Commission are the charges for message switching, data processing, and special information services; the circumstances and public policies favoring regulation on the one hand and open competition on the other; the effectiveness and adaptability of ratemaking and other administrative procedures for the promulgation of tariff schedules in this industry; the adequacy of common carrier transmission facilities for computer services; and the measures that might be required to insure privacy and protect proprietary rights in data transmitted over communications facilities. Id. at 14,755. 


\section{A. The Services and Facilities Involved}

In the typical computer information service, the user introduces his raw information into the system by means of equipment located at a convenient terminal, from which the data are transmitted to the computer over communication lines. The computer performs the required operations on the data, and the processed data are then retransmitted to the user. This basic system can be utilized in a number of ways to furnish services that require computer access for problem solving or record maintenance. For example, computer/communication services can provide a medical information bank for diagnosing diseases, an index of cases to facilitate legal research, a nationwide credit information bureau, transportation reservation services, current inventory information, and automated libraries to process information requests from remote locations. The development of these and other services depends both on continued technical advances and on the extent to which the companies furnishing the services will come under federal regulation.

Centralization in computer/communication services has been undertaken to optimize hardware costs and to increase efficiency by enabling many small users to participate in a multi-access system on a time-sharing basis. The trend toward centralization could alter the nature of competition within the industry and affect the diversity of services offered. As the demand for computer services expands, it will become more and more advantageous to include a maximum amount of communications facilities in order to decrease the time necessary to provide access to the computer. ${ }^{3}$ Since communications services provided by common carriers are subject to federal regulation, their combination with data processing and other computer functions raises regulatory problems. By offering services that include the use of computers, communications common carriers are coming into competition with computer manufacturers, service bureaus, and other nonregulated firms that depend on the carriers for fairly priced communications circuits. On the other hand, while common-carrier activities such as circuit switching by means of electro-mechanical

3 It has been estimated that more than half of the nation's computers will be tied into public communication systems by 1975 . Address by Russell W. McFall, President, Western Union Telegraph Co., "The Age of the Communicator," before the Industrial Communications Association, in Montreal, Canada, May 2, 1966, at 4, quoted in Irwin, The Computer Utility: Competition or Regulation?, 76 Y ALE L.J. 1299, 1300 n.3 [hereinafter cited as Irwin]; Address by Bernard Strassburg, Chief, Common Carrier Bureau of the FCC, "The Communications Carriers and Management Information Systems," before the Institute on Management Information and Data Transfer Systems, at American University, Washington, D.C., Oct. 21, 1965, cited in Comment, Computer Services and the Federal Regulation of Communications, 116 U. PA. I. REv. 328 n.2 (1967) [hereinafter cited as Computer Services]. 
devices have historically been subject to federal regulation, there is doubt whether common-carrier regulation can apply to circuit and message switching performed by noncarriers.

Generally, the services provided in the computer information field can be divided into two types: message switching and data processing. While the continual development of computer technology makes classification difficult, and while the distinction between message switching and data processing loses validity in direct proportion to the sophistication and complexity of the computer hardware and software, these categories are the best currently available for legal analysis. Message (or circuit) switching involves receiving, examining, storing, processing, routing, and transmitting a customer's message. Typically, the incoming message is punched on tape; the computer changes the message into electronic impulses, determines routing, and switches the message to the proper outgoing channel. If all of the channels to the destination are busy, the message is stored in the computer's memory drum until there is an available channel. Customer billing information is compiled and a monitor copy of the message is recorded on magnetic tape for future reference. ${ }^{4}$ As message switching functions become more sophisticated, they will include additional distribution operations and utilize various means of communication transmission such as wire lines, satellites, coaxial cables, radio, or combinations of these.

The switching function can be defined as the interconnection or transfer of electrical signals from one channel to another. If done by direct electrical connection of the channels, it is line switching, and if delayed through a "store and forward" medium, it is message switching. 5 The switching center can send messages to a number of addresses either through the use of a short code that the computer interprets as a group of addresses, or through the use of multiple addressing where all of the addresses are included at the beginning of the message. Additional information such as the date, time of day, or number of prior messages sent can be inserted into a message. The use of a computer makes it possible to maintain a history tape from which messages can be retrieved. By using a computer for message switching, it is also possible to develop a message routing system based on a predetermined desirability pattern. This categorization of message desti-

4 The RCA Communications Electronic Telegraph System utilizes two computers of which "the standby or backup computer performs many off-line processing functions such as preparing the journal tapes so that accounting and billing information can be extracted from them." Branch, Communications via Computers: What are the Extras?, 9 DATA Processing 530 (1966) (Proceedings of the 1965 Fall Conference and Business Exposition, Data Processing Management Association).

5 See Data Communications in Business 138-41 (E. Gentle ed. 1965). 
nation could be considered a function beyond ordinary message switching and very near to data processing.

Data processing can be described as the transformation of information, including such functions as analyzing, classifying, correlating, summarizing, storing, and retrieving data. The basic data processing sequence is "(1) to originate data, (2) to manipulate, according to some plan, the new data and files prepared in an earlier cycle, and (3) to report results." 8 The word "data" means particular facts, as opposed to "information," which represents the totality of facts that are desired. Put another way, information derives from data.

Data collection is not generally considered to be part of the data processing operation. In data collection, the data are transformed from their original state to one usable for the conversion process. They must either be machine-processable or in a form that can be recorded on paper punch cards or tape. Then data conversion is accomplished through the use of audio tape recorders or automatic voice-to-digital converters, depending on the volume of data involved and the financial investment allowed for various parts of the operation. At this point the data are verified to insure that a specified format is not being altered or violated. While data collection and data verification are probably not parts of the data processing function, data conversion could arguably be included. Strictly speaking, however, data processing does not begin until the data are classified by type and ordered into some sequence. This rearrangement of the input data constitutes the first alteration in the content of the data.

As new uses are found for computers, it will become more difficult to isolate any particular process. For example, file processing includes updating and converting data for business purposes, summarizing business transactions, recognizing exceptional circumstances, and searching for additional material. While all this is taking place the computer performs a number of processing operations to insure accurate results. It verifies data by comparison with facts already in the files, it controls input data to guard against losing valid transactions, and it constantly checks arithmetical accuracy by repeating operations or by performing them in parallel through separate channels. These activities are usually included in the "main stream" of data processing; any additional procedures used to ensure accuracy are considered to be supplemental. ${ }^{7}$ However, it is not clear at what stage other processes

6 R. Gregory \& R. Van Horn, Automatic Data-Processing Systems 5 (2d ed. 1968). For a short history of computers and data processing, see C. GotTLIEB \& J. Hume, High Speed Data Processing 1-4 (1958).

7 R. GREGoRY \& R. VAN HoRN, supra note 6 , at 9-10. 
may be considered outside of the main stream of processing, and it is doubtful whether this phrase can be used to define legal classifications. ${ }^{8}$

It is possible to make functional distinctions between various other data processing operations, but the distinctions are of doubtful legal utility. For example, a "closed-loop" system is fully automatic at all stages from data origination to processing and back to the implementation of control, whereas an "open-loop" system employs people for either data gathering or carrying out control instructions. ${ }^{9}$ An "on-line, real-time" system obtains data about operations while they are occurring, processes the data, and furnishes the results quickly enough to be useful in controlling the outcome of the process. By using the computer to collect data, the data can be checked for reasonableness, format, and transmission errors. ${ }^{10}$ In an "off-line" system there is no direct control of the central processing unit, and the data collection operation need not be directly connected to it.

Another distinction can be made between information retrieval and data processing. In the former case the computer retrieves information stored in its memory bank, as in a legal reference service. In the latter case the processing function would be added to the service and the content of the data would be changed. However, if after data is retrieved, the remaining store of information is altered to reflect the new set of circumstances, this could be said to constitute data processing.

To "process" is to change the form of data substantially, and a similar meaning could be given to "reconstruct" or even to "transpose." "Format conversion" is a borderline operation, since it could conceivably be accomplished without actually processing the data. Since the computer industry has accepted "process" as a description of a broad category of computer activities, it might be preferable to develop new concepts such as "reconstruction" and "transposition" to further segregate and delimit the bounds of processing activities. If this were done, it would be easier to mark the place on the continuum where message switching evolved into some sort of a processing function. Another possibility would be to develop criteria based on the nature of the material extracted-whether it was crucial to the functioning of a service or merely a byproduct-or to consider the extent of the

8 Although the text considers only the processes involved in input preparation, output preparation consists of many equally divergent operations, performed to place the data in a form acceptable to the customer.

9 See generally, R. GREGORY \& R. VAN HORN, supra note 6, at 16-18.

10 See generally, Data Communicatrons in Business, supra note 5, at 81-95. For a discussion of the special features and peripheral devices of data processing equipment, see R. GREGORY \& R. VAN HORN, supra note 6 , at $127-56$. 
treatment that the extracted material received. For example, there might be a viable distinction between material used by the common carrier simply for an accuracy check, and material transmitted ${ }^{11}$ for use by the customer as a part of his business activities.

\section{B. The Computer/Communication Industry}

A number of different types of firms have an interest in the computer/communication industry because of their ability to provide the new services and their desire to maximize their share of the expanding market. Of initial interest are the electronic data processing manufacturers. ${ }^{12}$ IBM, the largest of this group, is forbidden by a 1956 consent decree from engaging in explicit service bureau activities, ${ }^{13}$ but nevertheless has developed a plan whereby a customer brings data to the IBM data center, processes it himself, and is billed only for computer time. IBM uses standard hardware in connection with a software package specially designed to fit each customer's needs. IBM

11 Data transmission takes place via some form of electrical or electronic circuit. Wires, cables, and microwave circuits are supplied by the communication common carriers. Circuits are classified by the rate at which they transmit data. A teletype channel (low-rate) utilizes a teletypewriter, which is basically an electric typewriter that can be operated manually or by reading a perforated paper tape. A teletypewriter can be connected to a leased or dial-switched telegraph circuit for transmitting text and data in readable form. Teletype is the trademark of the Teletype Corporation and usually refers to a set of equipment containing transmitters, tape punches re-perforators, and page printers. Teleprinter exchange services provide dialed connections between any two points on the teletype networks. The maximum rate of data transmission over a telegraph circuit is 10 characters per second.

Telephone channels (intermediate-rate) have a speed of up to several hundred characters per second. Leased circuits have a maximum rate of 300 characters per second; dial network circuits have a maximum of 250 characters for local service and 150 characters for long-distance circuits.

A micro-wave circuit (high-rate) can be used for several hundred telephone channels, several thousand teletype channels, or several Telepak channels. Telepak channels are broad-band channels for transmitting data to and from magnetic tape or directly between computers at 60,000 characters per second. Private microwave systems are limited by the need for relay stations within twenty miles of each other.

Modulation units called Data-Phones translate data into electrical form suitable for transmission. They replace the telephone with a device that connects to an input reader. In a dial service the modulator contains not only the dialing mechanism but also a telephone for voice communication before and after the data communication. In terms of a chain of events, the following occurs up to the point of processor input: detection of events, translation of events into symbols, recording the symbols as data, converting the data into processable form, transmission of data to the processor for read-in via some form of communication channel, input data conversion, and input reading. $R$. GREGORY \& $R$. VAN HORN, stipra note 6 , at 105 ; see Pierce, The Transmission of Computer Data, ScIentric AMERICAN, Sept. 1966, at 144-60.

12 Companies in this category include General Electric, Honeywell Inc., RCA: Electronic Data Processing, Scientific Data Systems, and IBM. In addition to manufacturing hardware, General Electric has developed general and specialized computer services, including information retrieval services for legal precedents, stock quotations, and credit references; these services utilize regional computers to reduce transmission costs. Honeywell Inc. restricts itself to supplying peripheral equipment. Scientific Data Systems produces individualized computers that offer privacy, security, and prestige.

13 United States v. IBM. 1956 Trade Cas. đ68, 245 (S.D.N.Y. Jan. 25, 1956). 
prefers federal regulation of communication links provided by common carriers for computer information services, but no control over noncarriers that provide services including incidental message switching. On the other hand, IBM favors nonregulation of common-carrier data processing services, since the next logical step would be regulation when these services were provided by noncarriers.

In an attempt to present a united front in the computer inquiry, the equipment manufacturers, through the Business Equipment Manufacturers Association (BEMA), established an ad hoc committee in May of 1966 to study the relationships between communications common carriers and the data processing industry. This committee evolved into the Committee on Relationships with Communications Carriers, which prepared a response for the FCC, stressing the desirability of nonregulation. It was pointed out that regulation would retard technological development, require new equipment to be tariffed even if specially designed for the customer, result in uniform pricing without regard to accessibility or availability, and make accounting methods a matter of public record.

A large number of diverse service bureaus lease or buy computers, lease communication lines, and then provide a computer information service to customers. Service bureaus have come into competition with private businesses that have excess computer capacity to use. ${ }^{14}$ Banks, for example, have developed computer facilities to handle payroll, investment, cost, and tax work for their customers. As banks introduce more computer services, it will be advantageous for them to offer these services to others in addition to their regular customers. ${ }^{15}$

In Minnesota, a group of data processing companies have brought suit to prevent a St. Paul bank from selling computer services to the public. $^{16}$ The data processers claim that the bank's preparation of computerized payroll records for client companies is doing "substantial and irreparable harm" to the data processors' business. The bank considers data processing operations an integral part of its payroll business, or in any event, an incidental service that comes within a liberal interpretation of the federal statutes, particularly the congressional authorization for bank service corporations to make auto-

14 Address by Bernard Strassburg, supra note 3.

15 The problems raised by bank expansion into commercial data processing are discussed in Hearings on Legislation to Prohibit Banks from Performing Certain NonBanking Services and from Engaging in the Business of Personal Property Leasing Before the Subcomm. on Bank Supervision and Insurance of the Honse Comm. on Banking and Currency, 89th Cong., 2d Sess. 121 (1966) (testimony of Herbert W. Robinson of ADAPSO), cited in Irwin, stpra note 3, at 1301 n.5.

${ }^{16}$ N.Y. Times, Aug. 17, 1967, at 53, col. 4; Telephone conversation with the legal department of the American Bankers Association, Aug. 18, 1967. The American Bankers Association is attempting to intervene as a friend of the court. 
matic data processing services available to the banking community. ${ }^{17}$

The federal government also has an interest in the development of computer information services, since it owns or leases about half of the computers now in use in the United States. ${ }^{18}$ The interest shown in establishing a Federal-State Telecommunications Advisory Committee to develop policy on computer usage ${ }^{19}$ indicates governmental concern with the need for standardization and compatibility in computer techniques. It is improbable that a government data processing network separate from the private systems will be developed, ${ }^{20}$ but the government is concerned as a customer with the extent of regulation to be imposed on the private companies and the communications common carriers.

Competition among the communications common carriers is modified by the special circumstances surrounding their operations. The American Telephone and Telegraph Co. (AT\&T) and its subsidiaries are enjoined by a consent decree from manufacturing for sale or lease any equipment that will not be used by the Bell System companies in furnishing common carrier communication services, and from engaging either directly or through subsidiaries in any business other than furnishing common carrier communications services, except for business or services incidental to the furnishing of such services. ${ }^{21}$ Hence, there could be AT\&T competition in the computer information industry only to the extent that AT\&T's computer business qualified as common-carrier activities or as services incidental to such activities.

The primary service performed by Western Union is message switching, but it is embarking on an extensive program designed to create a computerized management information service that will provide computer hardware, software, and communications circuitry to the customer. Each system will be engineered individually to fit the customer's needs. ${ }^{22}$ Radio Corporation of America (RCA) has an interest in the communications aspects of the computer information industry through RCA Global Communications, Inc., and a stake in the manufacturing aspects through RCA: Electronic Data Processing $(\mathrm{RCA}: \mathrm{EDP})$. RCA:EDP is the only manufacturer of data processing equipment that has a corporate association with a common

1712 U.S.C. $\$ 1861$ (1964). The statute was intended to authorize use of automated equipment. S. REp. No. 2105, 87th Cong., 2d Sess. 1 (1962).

18 See Bureau of the Budget, Inventory of Automatic Data Processing Equipment in the Federal Government, June 1965.

1933 Telecommunications Rep., No. 13, Mar. 13, 1967, at 1-5.

20 See Irwin, supra note 3 , at 1318-19.

21 United States v. Western Elec. Co., 1956 Trade Cas. \68,246 (D.N.J. 1956).

22 Letter from Western Union Telegraph Co. to FCC, Apr. 14, 1967, at 3. 
carrier; although International Telephone and Telegraph (ITT) and General Telephone both have subsidiaries that produce equipment, they do not presently sell commercial computers.

The existence of a number of corporate structures able to furnish computer/communication services places an initial constraint on the FCC Inquiry. It would seem that fairness and consistency require FCC regulation of all entities offering a particular service, or of none. For example, there would be obvious discrimination if communications common carriers were required to file tariffs on computer/communication services, thereby restricting their pricing practices and marketing efforts, while similar services by computer manufacturers and service bureaus were left unregulated.

\section{Terminology}

A thorny semantic problem is raised by the necessity for a term to describe the industry that combines computer and communication services and facilities. It is possible that the phrase adopted might connote either regulation or free competition. For example, the word "utility" commonly refers to a regulated activity, and fear has been expressed that the use of "utility" would result in a bias in favor of regulation. ${ }^{23}$

Specific functions involved in the mix of services offered by the industry might be separately classified. For example, message switching could be considered a utility service, and data processing could be classified as a nonutility service. But such separation would be technologically unsound in many cases, ${ }^{24}$ and might induce industry attempts to design systems and equipment in order to avoid regulation rather than to improve service.

$23 \mathrm{M}$. Irwin, Computers and Communications : Toward a Computer Utility, Mar. 21, 1967, at 1 (unpublished manuscript presented at the U.C.L.A. Symposium on Computers); D. Parkhill, The Computer Utility-Concepts and Categories, Mar. 8-10, 1967 , at 3 (unpublished manuscript presented at a briefing session of the American Management Association).

There is evidence that the term "utility" may be gaining general acceptance:

The terms Computer Utility and Information Utility are now being increasingly employed to denote a new class of information systems which employ communication links and the technique of time and space sharing to make available a wide range of information processing services directly to customers in their places of business or homes.

Id. 1. See also Irwin, supra note 3 , passim.

24

There are strong technical reasons, especially when the switching aspects are considered, for regarding communications and data processing in the computer utility as being logically inseparable.

D. Parkhill, supra note 23 , at 5 . 
The phrase used in this article to refer to the combination of message switching and data processing activities is "computer information services." While the phrase "computer communication services" might be equally acceptable, it will become less accurate if technological developments bring the service to the point where the communication aspect is secondary to the information capability of the system. ${ }^{25}$ The word "service" is intended to be neutral to the extent of avoiding the regulatory overtones of "utility" but indicating that regulation might be required if demonstrated to be in the public interest.

\section{The Legal Tests for a Communications Common Carrier Service}

Computer information services will be subject to existing federal regulation if the FCC finds them to be common carrier communications as defined in the Communications Act. Section 203(a) provides:

Every common carrier . . . shall . . . file with the Commission and print and keep open for public inspection schedules showing all charges for itself and its connecting carriers for interstate and foreign wire or radio communication .... ${ }^{26}$

Section 203(c) continues:

No carrier, unless otherwise provided by or under authority of this chapter, shall engage or participate in such communication unless schedules have been filed . . . . 27

These sections raise two crucial questions of definition: first, whether computer information services constitute "wire or radio communication," and second, whether the entity that provides the services is a "common carrier."

\section{A. "Communication by Wire"}

Section 3(a) of the Communications Act defines "communication by wire" as

the transmission of writing, signs, signals, pictures, and sounds of all kinds by aid of wire, cable, or other like connection between the points of origin and reception of such

25 It should be acknowledged that the rapid development of computer technology may qualify the validity of any classification.

2647 U.S.C. $\$ 203$ (a) (1964) (emphasis added).

$27 I d . \S 203(\mathrm{c})$. 
transmission, including all instrumentalities, facilities, apparatus and services (among other things, the receipt, forwarding and delivery of communications) incidental to such transmission. ${ }^{28}$

"Radio communication" is defined by section 3(b) to mean the transmission by radio of the same communications described in section $3(\mathrm{a})$, and to include the same incidental services and facilities. ${ }^{29}$

The difficulties in determining the applicability of this antique statutory framework to a modern technology are plain. Computer information services do not involve "communications" in the same sense that traditional telegraph, wire, and radio services did. But the statutory inclusion of "receipt, forwarding, and delivery of communications" indicates that "wire or radio communication" was intended to refer to the total service of a communications operation, involving wire facilities for the transmission of electric impulses, and instrumentalities for receiving, forwarding; and directing them.

Some computer information services at least arguably fit the statutory definition of "communication by wire." One example is the on-line, real-time stock quotation service involved in the Bunker-Ramo controversy. ${ }^{30}$ The basic quotation service, Telequote III, stores updated information concerning listed securities in computers that a broker can telephone to obtain the latest price and sales information. Telequote IV, which became the subject of dispute when Western Union refused to provide private lines for it, was designed to add a data-processing and message-switching capability to the basic quotation service.

Telequote IV would permit a buy or sell order from a particular branch office of a broker to be sent to and stored in a regional computer until polled by a central computer, checked for parity and forwarded to the broker's office or to the broker's representative on the floor of the exchange. Execution orders would be routed back to the branch office from which they originated in similar fashion. In addition to this message-switching service, Telequote IV was to afford information storage and processing services with respect to margin accounts and financial research. ${ }^{31}$

Telequote III involves facilities for the receipt and transmission of communications by a Bunker-Ramo computer over wire facilities.

$28 I d . \$ 153$ (a) (emphasis added).

$29 \mathrm{Id}$. $\$ 153(\mathrm{~b})$.

${ }^{30}$ For a discussion of this service, see Computer Services, supra note 3, at 329-40.

31 Id. 329 (footnotes omitted). 
Telequote IV would have added the additional service of "forwarding" messages from one location to another. Both services seem to contain sufficient elements of "communication by wire" to fit the statutory definition. Especially in Telequote IV, the Bunker-Ramo facilities would perform many of the same switching, routing, and transmission functions involved in traditional telegraph or telephone terminal operations.

There are two levels upon which the term "services" can be viewed in the Communications Act. On one level, "services . . . incidental to such transmission" are included within the definition of "communication by wire." 32 On another level, section 202(b) provides that

services, whenever referred to in this chapter include . . . services in connection with, the use of common carrier lines of communication, whether derived from wire or radio facilities, in chain broadcasting or incidental to radio communication of any kind. ${ }^{33}$

Even if computer information services could not be considered incidental to wire or radio communication, they might be considered services in connection with the use of common carrier lines. To the extent that computer information services contribute to the speed and efficiency of communications, treating them as incidental services appears to come within the purpose of the Communications Act "to make available . . . a rapid, efficient, Nation-wide and world-wide wire and radio communication service . . . ." 34

It has been suggested that since the Communications Act refers only to the transmission of signals, the transformation of signals is beyond the scope of the Act. ${ }^{35}$ Apparently, under this suggestion

32 Communications Act $\$ 3(a), 47$ U.S.C. $\$ 153$ (a) (1964).

3347 U.S.C. $\$ 202$ (b) (1964).

34 Communications Act $\$ 1,47$ U.S.C. $\$ 151$ (1964).

35

Section 3 of the Act defines both wire and radio communications as "the transmission of writing, signs, signals, pictures, and sounds of all kinds." This definition does not extend to the transformation of data or intelligence, at least for any purpose not directly contributing to the efficient and accurate transmission of messages from one person or location to another. The transforming functions performed in the processing of data, such as analyzing, classifying, correlating, sorting, calculating, summarizing, producing records and reports, and constructing and applying formulae are not "transmission" and are therefore not communication services within the meaning of the Act.

The data processing business, like most other activities, often has significant incidental communications aspects, but this does not convert the data processing to communications.

Letter from Burke Marshall, Vice President and General Counsel, International Business Machines Corp., to B. F. Waple, Secretary, FCC, Feb. 15, 1966, at 2. 
message switching would fall within the jurisdiction of the FCC, although data processing would not be subject to regulation. However, one interpretation of section 3 of the Communications Act takes account of services incidental to wire or radio communication, and it may be possible to consider the transformation of data such a service, since it contributes to the efficient and accurate transmission of messages. Similarly, data transformation could be considered a service in connection with the use of common carrier lines within the terms of the Act. A computer information service could readily be considered a service incidental to or in connection with a communication service when it was included as an inseparable part of the service, as in the Securities Industry Communication (SICOM) service offered by the Western Union Telegraph Company. ${ }^{36}$

\section{B. "Common Carrier"}

The second prerequisite for regulation of computer information services is that the entity supplying the service be a "common carrier" within the terms of the Communications Act. Section $3(\mathrm{~h})$ provides:

"Common carrier" or "carrier" means any person engaged as a common carrier for hire, in interstate or foreign communication by wire or radio or in interstate or foreign radio transmission of energy, except where reference is made to common carriers not subject to this chapter; but a person engaged in radio broadcasting shall not, insofar as such person is so engaged, be deemed a common carrier. ${ }^{37}$

The phrase "any person engaged as a common carrier for hire" is not further defined in the Communications Act, and the legislative history of the Act indicates only that press associations are to be excluded and "that the definition does not include any person if not a common carrier in the ordinary sense of the term ...." 38 Given the unique nature of computer information services, it is questionable whether they fall within the ordinary sense of the term.

Historically, the phrase "common carrier" has been used to refer to the carriage of freight and passengers by stage coaches, motor vehicles, railroads, and airlines as well as the carriage of communications and other public utility services. One characteristic of these services was that they were provided by

one who holds himself out to the public as engaged in the business of transportation of persons or property from place

${ }^{36}$ This service is discussed in the text accompanying notes 84-87 infra.

3747 U.S.C. $\$ 153(\mathrm{~h})$ (1964).

38 H.R. Conf. Rep. No. 1918, 73d Cong., 2d Sess. $45-46$ (1934). 
to place for compensation, offering his services to the public generally. The distinctive characteristic of a common carrier is that he undertakes to carry for all people indifferently .39

The requirement that there be a general holding out to the public has been used by the FCC to define the common carrier concept. In one of the cases dealing with community antenna television systems, the Commission described a communications common carrier in the following terms :

Fundamental to the concept ... is that such a carrier holds itself out or makes a public offering to provide facilities by wire or radio whereby all members of the public who choose to employ such facilities and to compensate the carrier therefor may communicate or transmit intelligence of their own design and choosing . . . . ${ }^{40}$

The requirement that a common carrier in the transportation industry hold itself out to the public generally was accompanied by a requirement that the carrier charge uniform rates.

[T] here has been no such holding out if, in the regular operation of that business, the carrier, by act and deed, with or without words, claims to and exercises the right to fix specific rates in each individual case basing the charge not on a regular schedule (whether formally filed as tariffs or otherwise), but on contemporary judgment of the moment. For this is an effectual announcement that the carrier will discriminate, will undertake transportation differently not indifferently. ${ }^{41}$

While generally a common carrier is required to offer a service indiscriminately to all, there can be specialization in one class of goods or an offering to a specific segment of the public as long as the offering is indiscriminate within that segment. Computer information services are usually offered to the business community, with their form varied to adapt to special requirements that the user may have. But while the holding out of computer information services may be sufficiently general to justify common carrier classification, the charges for these services may vary sufficiently with customer needs that they would not comply with the indiscriminate rate requirement.

39 Kelly v. General Elec. Co., 110 F. Supp. 4, 6 (E.D. Pa. 1935), cited favorably in Tilson v. Ford Motor Co., 130 F. Supp. 676, 678 (E.D. Mich. 1955).

40 Frontier Broadcasting Co. v. Collier, 16 P \& F Radio REg. 1005, 1008 (1958). 41 Home Ins. Co. v. Riddell, 252 F.2d 1, 4 (5th Cir. 1958). See also McCallum v. United States, 298 F. 373 (9th Cir.), cert. denied, 266 U.S. 606 (1924). 
The determination whether a particular entity is a communications common carrier can also be made by reference to the nature of the service performed. ${ }^{42}$ In the CATV controversy, the FCC developed a distinction between communications whose content is determined by the user of the service, and communications whose content is determined by the carrier. ${ }^{43}$ In a communications common carrier service,

the carrier provides the means or ways of communication for the transmission of such intelligence as the subscriber may choose to have transmitted. The choice of the specific intelligence to be transmitted is . . . the sole responsibility or prerogative of the subscriber and not the carrier. ${ }^{44}$

The CATV system in Frontier Broadcasting Co. v. Collier ${ }^{45}$ was held not to be a common carrier service because "the specific signals received and distributed by the CATV system are, of necessity, determined by the CATV system and not the subscriber." 46

In Subscription Television Inquiry, ${ }^{47}$ this distinction was stated another way:

It has been a fundamental concept in the communications field that a person is not a "common carrier" of communications where he is providing his subscribers primarily with a news or information service, rather than with a communication service enabling subscribers to communicate among themselves. Thus for example, while the furnishing of leased wires or radio circuits by the telephone or telegraph carriers is part of their common carrier activities, the use of such leased wires by the news services to transmit news to their subscribers, or by the stock exchange to transmit price quotations has been held not to involve common carrier operations. ${ }^{48}$

It has been pointed out that this reasoning may serve to exempt from regulation those computer information services, like BunkerRamo's Telequote III, that limit transmission to data summoned

42 Cf. Washington ex rel. Stimson Lumber Co. v. Kuykendall, 275 U.S. 207, 211-12 (1927).

43 Frontier Broadcasting Co. v. Collier, 16 P \& F Radio Reg. 1005 (1958); CATV \& Repeater Servs., 26 F.C.C. 403 (1959); WSTV, Inc. v. Fortnightly Corp., 23 P \& F RAdro REg. 184 (1962); Industrial Radiolocation Serv., 8 P \& F Radio REG. 2D 1545 (1966) ; all cited in Computer Services, supra note 3, at 340-41 nn.54-55. 44 Frontier Broadcasting Co. v. Collier, 16 P \& F Radio REg. 1005, 1009 (1958) 4516 P \& F Radio Reg. 1005 (1958).

$40 \mathrm{Id}$. at 1009 .

477 P \& F Radio Reg. 2D 1501 (1966).

$48 \mathrm{Id}$. at 1513. 
from a computer by the user without providing communication to a third party. ${ }^{49}$

Another possible source of FCC authority over computer information services is to be found in sections $4(i)$ and $303(r)$ of the Communications Act:

The Commission may perform any and all acts, make such rules and regulations, and issue such orders, not inconsistent with this chapter, as may be necessary in the execution of its functions. 50

$[\mathrm{T}]$ he Commission . . . shall- $[\mathrm{m}]$ ake such rules and regulations and prescribe such restrictions and conditions, not inconsistent with law, as may be necessary to carry out the provisions of this chapter. . . . ${ }^{51}$

Although a liberal interpretation of these sections would indicate the existence of extensive regulatory authority, this authority has been construed narrowly to allow only those actions reasonable and necessary in carrying out the statutory powers. ${ }^{52}$ Denials of licenses and threats of denials are the only sanctions available to the Commission; it cannot order the disaffirmance of a specific contract, ${ }^{53}$ nor can it base regulation on a broader interpretation of a criminal statute than Congress intended, ${ }^{54}$ even though the interpretation might reasonably cure existing defects or ills in the field. ${ }^{55}$

49 Computer Services, supra note 3 , at 340.

5047 U.S.C. $\$ 154$ (i) (1964).

51 Id. $\S 303(\mathrm{r})$.

52 Cf. Federal Radio Comm'n v. Nelson Bros. Bond \& Mortgage Co., 289 U.S. 266, 281 (1933); Clear Channel Broadcasting Serv. v. United States, 284 F.2d 222 (D.C. Cir. 1960) (upholding order that was broad, but not "arbitrary, capricious, or an abuse of the Commission's discretion") ; Bendix Aviation Corp. v. FCC, 272 F.2d 533 (D.C. Cir. 1959) (sustaining denial without hearing of application for experimental use of particular frequency for development of airborne aircraft collision-preventive system on grounds that FCC action pursuant to $\$ \$ 4(i)$ and $303(r)$ among others was not arbitrary or capricious).

53 Regents of Univ. Sys. of Georgia v. Carroll, 338 U.S. 586, 600 (1950) : One suggestion is that petitioner's position has a specific statutory basis in $\$ 303(\mathrm{r})$, which permits the Commission to prescribe such "conditions" as are "necessary to carry out the provisions" of the Act. We do not think the suggestion is sound. Congress has enabled the Commission to regulate the use of broadcasting channels through a licensing power. It is in connection with this power that $\S 303(r)$ is to be interpreted.

54 FCC v. American Broadcasting Co., 347 U.S. 284 (1954).

55 With regard to lotteries, the Court in American Broadcasting commented: [The FCC] unsuccessfully sought to have the Department of Justice take criminal action against them. Iikewise, without success, it urged Congress to amend the law to specifically prohibit them. The Commission now seeks to accomplish the same result through agency regulations. In doing so, the Commission has overstepped the boundaries of interpretation and hence has exceeded its rule-making power.

Id. at 296 (emphasis added). 
If regulation of computer information services is found to be within the jurisdiction of the FCC, control will be circumscribed by the authority granted in the Act, ${ }^{56}$ as is the case with all agency power. ${ }^{57}$ But even if a grant of authority is found that can be interpreted to apply to computer information services, the FCC will have to determine the necessity for regulation, and whether or not control over this industry would be appropriate to the rationale of the Communications Act. Relevant to such a determination are the possibilities for optimum development in either a regulated or an unregulated state. If rapid, efficient service with adequate facilities at reasonable charges would be most likely to evolve under open competition, then a reasonable approach would call for freedom from regulation. The opposite would be true if it could be shown that regulation was necessary in the public interest.

Several of the problems of interpretation raised above have been considered in relation to FCC attempts to exert jurisdiction over the activities of community antenna television (CATV) or cable television systems, ${ }^{58}$ and it would appear that some of the arguments apply with equal force to computer information services. Although there seemed to be a predisposition towards liberal construction of the Act in the cable television controversy, ${ }^{59}$ based on a desire to prevent practices inimical to the public interest, the FCC still had to base its regulation on a specific provision in the Communications

56 Stark v. Wickard, 321 U.S. 288, 309 (1944) ; cf. Peters v. Hobby, 349 U.S. 331, 345 (1955):

Agencies whether created by statute or Executive Order, must of course be

free to give reasonable scope to the terms conferring their authority. But

they are not free to ignore plain limitations on that authority.

57 See American Trucking Ass'n v. United States, 344 U.S. 299, 314-15 (1952) (ICC must have reasonable grounds for its judgment; "the rules [must] represent, at best, a compromise between stability and flexibility of industry conditions, each alleged to be in the national interest") ; National Broadcasting Co. v. United States, 319 U.S. 190, 219-20 (1943) (standards for FCC's judgment should be "adequately related in their application to the problems to be solved") ; NLRB v. Atlantic Metallic Casket Co., 205 F.2d 931, 936 (5th Cir. 1953) ("[t] he board is governed strictly by the statute from which it derives its existence") ; Colorado Interstate Gas Co. v. FPC, 142 F.2d 943, 952 (10th Cir. 1944). See also NLRB v. Highland Park Mfg. Co., 341 U.S. 322 (1951).

58 See generally FCC Memorandum on Jurisdiction and Authority, Appendix B, Regulation of CATV Systems, Dkt. No. 15971, 4 P \& F RADIo REG. 2D 1707 (1965); Second Report on CATV Regulation, Dikt. No. 14895, 6 P \& F RADIO REg. 2D 1717, 1726-27 (1966).

50 In support of a liberal construction of the Act, the Commission cited National Broadcasting Co. v. United States, 319 U.S. 190, 217, 219 (1943), in its Memorandum on Jurisdiction and Authority, stpra note 58. "The avowed aim of the Communications Act of 1934 was to secure the maximum benefits of radio to all people of the United States. To that end Congress endowed the Communications Commission with comprehensive powers to promote and realize the vast potentialities of radio." 319 U.S. at 217. "In the context of the developing problems to which it was directed, the Act gave the Commission not niggardly but expansive powers." Id. at 219. 
Act. ${ }^{60}$ The Commission does not have the power to regulate all business activities that have an effect on a regulated service. ${ }^{61}$

It might be possible to introduce a reliance argument into the debate over federal control of computer information services in much the same way that this was done with regard to cable television systems. The alleged reliance of the parties was evidenced by their economic investment in a system that subsequently was found to be subject to a regulatory scheme that would have adversely affected their investment. ${ }^{62}$ The Commission balanced this reliance against concern for the "substantial economic threat" posed by cable television to other segments of the communications industry. ${ }^{63}$ Unable to obtain congressional guidance relative to cable television, the FCC was forced to rely on the powers of implied agency that give the Commission authority to deal with aligned activities that might affect a regulatory system entrusted to the agency. ${ }^{64}$ The obvious difficulty with discretionary action of this kind is that it must be based on a determination of the public interest that can easily be distorted in a given situation. ${ }^{65}$

60 See National Broadcasting Co. v. United States, 319 U.S. 190, 216, 219 (1943). 61

There is no doubt that Congress intended by these provisions [ $\$ \$ 4(i)$ and $303(\mathrm{r})$ ] to provide the Commission with a degree of flexibility in performing its important tasks. Such provisions, however, by their own terms, are to be measured by the Act and its structure and purpose.

Southwestern Cable Co. v. United States, 378 F.2d 118, 121 (9th Cir. 1967).

All authority of the Commission need not be found in explicit language . ... While the action of the Commission must conform with the terms, policies and purposes of the Act, it may use means which are not in all respects spelled out in detail.

Public Serv. Comm'n v. FPC, 327 F.2d 893, 897 (D.C. Cir. 1964).

62 Not until petitioners had incurred the expenses of installing necessary fixed facilities and acquiring subscribing customers did the Commission issue the order which, if enforceable, would adversely affect, if not destroy, the petitioners' investments. Southwestern Cable Co. v. United States, 378 F.2d 118, 124 (9th Cir. 1967) (Ely, J., concurring).

63 Carter Mountain Transmission Corp. v. FCC, 32 F.C.C. 459 (1962), aff'd, 321 F.2d 359 (D.C. Cir.), cert. dertied, 375 U.S. 951 (1963). For a discussion of relevant policy questions, see Note, Community Antenna Televisions: The New Federal Exercise of Jurrisdiction, 51 IowA L. Rev. 366 (1966).

64 See Buckeye Cablevision Inc. v. FCC, 387 F.2d 220, 225 \& n.20 (D.C. Cir. 1967); Philadelphia T.V. Broadcasting Co. v. FCC, 359 F.2d 282, 284 (D.C. Cir. 1966) :

Congress in passing the Communications Act of 1934 could not . . . anticipate

the variety and nature of methods of communication by wire or radio that would come into existence .... In such a situation, the expert agency entrusted with administration of a dynamic industry is entitled to latitude in coping with new developments in that industry.

For a further discussion of the FCC and cable television, see Jurisdiction of CATV Service and Channel Service for CATV Systems, in A.B.A. SEction of PuBLIC UTILITY LAw, ANNUAL RePORT 175-79 (1967).

65 FCC Second Report on Cable Television, Dkt. No. 14895, 6 P \& F Radro REG. 2D 1727, 1732-33 (1966). 
Not all activities affected with a public interest are subject to regulation, ${ }^{66}$ even when undertaken by communication common carriers. However, when a communications common carrier performs a nonregulated service, it is required to file a statement with the FCC giving a "description and full particulars" of the service. ${ }^{67}$ This disclosure requirement for any new service provided by a communications common carrier, whether covered by a tariff or not, may result in a competitive disadvantage, since noncarriers providing the service will not have to file a report. In the case of computer information services, the publication of operational particulars, pricing structures, and the full extent of services offered might mean that computer manufacturers and other unregulated companies could develop competitive services based on information made public by the carrier. On the other hand, it is in the public interest to have the FCC scrutinize the activities of communication common carriers in order to prevent attempts to avoid tariffs on services that should be regulated.

\section{The Primary Business Test}

In the transportation field, the Interstate Commerce Commission has developed a primary business test to determine whether a carrier that offers transportation for compensation as part of a noncarrier business is subject to common carrier regulation. ${ }^{68}$

It has long been established that the words "for compensation," . . . refer to that transportation supplied with a purpose to profit from the service performed as distinguished from transportation supplied merely as an incident to some other primary business, even though in the latter case a charge is collected which may or may not be identifiable as compensation for transportation. ${ }^{69}$

Although the FCC has not expressly adopted the primary business test, there is some indication that analogous considerations have been operative in FCC decisions. ${ }^{70}$

${ }^{60}$ Cf. Garkane Power Co. v. Public Serv. Comm'n, 98 Utah 466, 100 P.2d 571 (1940); Gulf Compress Co. v. Harris, Cortner \& Co., 158 Ala. 343, 48 So. 477 (1908). ${ }^{67}$ FCC RULES aNd Regulations $\$ 43.54$ : Reports regarding services performed by telegraph carriers.

${ }^{68}$ Red Ball Motor Freight Inc. v. Shannon, 377 U.S. 311 (1964); W. J. Golden, Jr., Common Carrier Application, 61 M.C.C. 57 (1952); Lenoir Chair Co., Contract Carrier Application, 48 M.C.C. 259 (1948), aff'd, 51 M.C.C. 65 (1949).

69 W. J. Golden, Jr., Common Carrier Application, 61 M.C.C. 57, 58 (1952).

70 See Industrial Radiolocation Serv., 8 P \& F Radio Reg. 2D 1545 (1966); Subscription Television Inquiry, 7 P \& F Radio REG. 2D 1501 (1966). Both cases are discussed in Computer Services, supra note 3, at 340-41. 
If the primary business test were applied to computer information services, communications functions incidental to a data processing service would not be subject to regulation. Although there quite possibly could be regulation when communication links are essential to fulfill a business purpose distinct from common carriage, if a computer was used for incidental message switching, data processing should be considered the primary service. Incidental communications services should also include messages transmitted between various parts of an information system, such as those needed to administer the operation and maintenance of the computers and associated communication facilities, or those used for coordinating functions like program scheduling.

The argument for the primacy of the data processing function in computer information services has been put forward by IBM ${ }^{71}$ and others. ${ }^{22}$ Bunker-Ramo urged that a kind of primary business test exempted its computerized stock quotation service from communications common carrier regulation. The thrust of the BunkerRamo defense was that the data processing services that were transmitted from the central data processing computer to the customers' offices used communication channels only incidentally to their primary service. Bunker-Ramo argued that communications lines were employed simply to bridge the geographic gap between the users and the central computer, that the communication service constituted only a small percentage of the overall operation, and that even if it were termed the transportation of communications it was only incident to another primary business and not supplied with the end of profit in mind. ${ }^{73}$ The message switching involved was allegedly not essential to the service, but was included merely to speed up the flow of intelligence and thus to increase the efficiency of the primary business of data processing. Bunker-Ramo pointed out that the relative size of the communications service was extremely small in comparison with the total service.

In an attempt to justify their analysis of the communications functions, Bunker-Ramo indicated by percentages the different types of messages that would be handled by the Telequote IV system: stock market quotation inquiries and replies, $84 \%$; orders and confirmations, $10 \%$; market opinions, $1 \%$; customer accounting data, $3 \%$;

71 Letter from IBM to the FCC, Feb. 15, 1966.

72 Committee on the Relationship with the Communication Common Carriers of the Business Equipment Manufacturers Association, Interim Statement, 1967, at 7-8. at 10 .

${ }^{73}$ Letter from Arnold, Fortas \& Porter to Bunker-Ramo Corp., Mar. 12, 1965, 
and miscellaneous administrative data, $2 \% .^{74}$ This analysis was challenged by AT\&T on the theory that message switching was the most significant part of the system, that any data processing that occurred was ancillary to the transmission of communications, and that therefore Telequote IV was essentially a common carrier undertaking subject to FCC regulation. ${ }^{75}$ Others pointed out that it was misleading to use percentage figures on traffic, since they did not have any necessary relation to the importance of the messages from a competitive and economic point of view. ${ }^{76}$

To counter these objections, Bunker-Ramo eliminated general message and administrative communications so that the service consisted of quotes and replies, orders and executions, margin requests and replies, and research and order follow-up requests and replies. The deletions did away with third-party communications that were not directly involved in the data processing services provided by the computer, and insured that all communications would be to or from the computer rather than switched through it. ${ }^{77}$ As thus constituted Telequote IV met the requirements of the AT\&T private line tariffs. ${ }^{78}$

Concern with the distinction between primary and incidental communications in Bunker-Ramo's computer information service was reflected in the allocation of percentages to the types of traffic to be carried, and in the eventual requirement that Telequote IV be confined to certain types of communication to and from the computer, not including message switching. ${ }^{79}$ The acceptance of the Bunker-Ramo service by the communications carriers demonstrates that there are combinations of data processing and communication services that do not contain sufficient communication functions to qualify as a regulated activity.

The FCC has asserted jurisdiction and subsequent tariff control over the Western Union marine news service, which consists of the

74 Letter from Arnold, Fortas \& Porter to the FCC, Aug. 23, 1965, at 1.

75 Letter from AT\&T to the FCC, Sept. 29, 1965, at 2.

76 Letter from Grove, Paglin, Jaskiewicz, Gilliam and Putbrese, attorneys for Ultronic Systems Corp., to the FCC, Jan. 17, 1966, at 1.

${ }^{77}$ Letter from AT\&T to Arnold, Fortas \& Porter, Feb. 16, 1966, at 1.

78 AT\&T's tariff required that a message "relate directly to the customer's business." American Telephone \& Telegraph Co., Tariff FCC No. 260, original at 17, issued Mar. 14, 1966, effective Oct. 16, 1966, quoted in Computer Services, supra note 3 , at 332. Western Union's tariff was arguably stricter, requiring that communications relate "solely to the customer's business." Western Union, Tariff FCC No. 237, original at 17, issued Mar. 14, 1966, effective Apr. 17, 1966, quoted in Computer Services, supra note 3 , at 330.

79 It should be noted that AT\&T eventually agreed to allow buy and sell orders, and the executions of buy and sell orders, to be handled over Telequote IV. Letter from Mr. Walter B. Kelley, Assistant Vice-President, American Telephone \& Telegraph Co., to Arnold \& Porter, Feb. 16, 1966, cited in Compnter Services, supra note 3 , at 331 n.15. 
collection and "interstate and foreign communication . . . of marine reports other than by ticker to subscribers of the company with respect to the movement of ships in the harbor of New York City." 80 Western Union's sports service has also been found to be a common carrier activity even though it involves the collection and telegraphic communication of information under a single charge. In deciding that the collection of sports information was included in a communications service, the Commission stated:

Western Union accepts and transmits intelligence on behalf of the owners thereof to persons entitled to receive the same, as a communications common carrier. The payment which Western Union makes to the baseball league is for the privilege of having the business and does not alter the character of the service rendered. ${ }^{81}$

Western Union's candygram service, long-distance shopping service, and flower-by-wire service are exempt from FCC regulation. In the floral delivery operation, Western Union uses the same facilities involved in its normal common carriage offerings. But the FCC has pointed out that Western Union properly segregates the charges for the communications segment of its floral service, and that wire communication is available at the same charges to persons desiring to obtain flower service from firms other than Western Union. ${ }^{82}$

The segregation of charges indicates that two separate services are being performed. The regular tariff charge based on the number of words and distance involved is made for the message sent; another charge is made for the flowers and forwarded, minus Western Union's commission, to the florist. The FCC found that the floral delivery service was a merchandising activity and should not be subject to regulation, ${ }^{83}$ Western Union had already filed a tariff on its shopping service, which exacted a charge for gift orders, and the Commission asked the company to withdraw this tariff on the basis of the flower service decision. However, the Commission did say that it would observe the operation of the flower delivery and gift order services, and their effect on the company's regulated activities, the implication being that if the unregulated services resulted in dis-

80 In re Western Union Telegraph Co., 10 F.C.C. 323, 323 (1944).

81 In re Western Union Telegraph Co., 14 F.C.C. 1026, 1029 (1950).

82 Letter from the FCC to the Hon. James Roosevelt, Chairman, Subcomm. on Distribution, Select Comm. on Small Business, U.S. House of Representatives, Nov. 5, 1964.

83 FCC Report on Western Union Intercity Flower Service, Dkt. No. 1964, Nov. 5,1964 , at 3 . 
crimination against users of the common carriage offerings, appropriate steps would be taken to relieve the burden.

In the case of Western Union's flower delivery and gift order services, communication functions were found incidental to a merchandizing operation. But in the case of Western Union's Securities Industry Communication (SICOM) Service, communication functions were found to dominate a data processing operation. ${ }^{84}$ The SICOM Service is a record (nonvoice) computer information and switching service designed for brokers. Western Union filed a tariff for the service, and objection was made on the ground that dataprocessing, noncommunication functions such as message retrieval, error checking, message ordering, and format regulation were included in the service. It was further alleged that additional noncommunication functions such as day-order matching, open order file maintenance, and research reporting would eventually be added to the service.

The principal question, as framed by the Commission, was "whether the package SICOM Service offering includes any significant noncommon carrier, noncommunication services." 85 It was decided that message switching by the computers was a significant communication function, and that the other functions were subsidiary to it.

For the most part each of these functions, although to be performed by an electronic computer, can, in one degree or another, find its counterpart in other common carrier communications services where a similar function may be performed manually or mechanically. This is not to say that each of these functions-when viewed apart from the transmission aspects of SICOM-would be clearly communication service. However, such functions when viewed in the full context of the tariff offering now before us, do not, at this time, warrant rejection or suspension of the tariff. ${ }^{86}$

It was pointed out that acceptance of this tariff prejudices neither the outcome of the Computer Inquiry, nor future Commission action if additional services are added to the package, nor a determination whether these services would be subject to regulation if performed by a noncarrier. Nevertheless, some guidelines are suggested by the FCC's analysis of the SICOM service. The Commission con-

84 In re Western Union Telegraph Co., 11 F.C.C. $2 d 1$ (1967).

$85 I d$. at 8.

86 Id. at 9. 
sidered the various computer functions within the context of the entire service, rather than isolating them and classifying them separately. There is at least an indication that certain activities-namely error checking and correction, usage reporting, format control, and message storage and retrieval-will be considered communication services when combined with message switching. Finally, the Commission indicated that it will look for functional similarities between computerized switching operations and those performed either manually or mechanically in the past.

The problems involved in segregating noncommunication components of computerized message switching services are even more complicated. ITT World Communications, Inc., has submitted and gained approval for a specific tariff on a computerized switching service called Automatic Re-transmission Exchange (ARX). ${ }^{87}$ The tariff does not include the communications circuits or terminal apparatus, but is based solely on the computer's message switching function. ${ }^{88}$ It is unclear whether approval of the ARX tariff precludes nonregulated computer manufacturers from operating computer switching systems, or indicates the necessity for tariffs to be filed on future extensions of the system's data processing capabilities. ${ }^{89}$

RCA Communications, Inc., has developed an automatic information and reservations computer oriented network service (AIRCON), which it reported to the FCC without submitting a tariff. ${ }^{90}$ AIRCON utilizes an electronic computer center in New York for message switching, account processing, reservations, inventory, and sales and cost analysis. Customers obtain private lines from communications common carriers at separate tariff rates; the AIRCON service is to remain un-tariffed. ${ }^{91}$ RCA's position is that it would be inappropriate to file a tariff for the service or take any other action that could be considered prejudicial to the Commission's computer inquiry, particularly since a tariff could have an adverse effect on the competitive position of the company. ${ }^{22}$

At present, the problem is to decide whether computerized message switching services that contain a data processing capability are subject to regulation. But it is likely that technological advances will result in data processing services with an integrated message

87 ITT World Communications Inc., Tariff FCC No. 54, Apr. 14, 1966.

88 Letters from ITT World Communications, Inc., to the FCC, Jan. 30, 1967, at 2 , and Feb. 27, 1967, at 4.

89 Irwin, supra note 3 , at 1312-13.

90 Letter from RCA Communications, Inc., to the FCC, Feb. 17, 1967, at 1.

01 Id. 2.

92 Letter from RCA Communications, Inc., to the FCC, May 5, 1967, at 5. 
switching capability. Such a development would make it harder to justify regulation of the entire service, and make some kind of separation according to function seem more attractive for purposes of regulation. The argument in favor of separation is that if the charges for communications lines are not isolated from the charges for data processing, a communications common carrier will be able to package the entire service at a lower price than its noncarrier competitors, by virtue of its inherent cost advantage as supplier of its own communication circuits. For complete competitive equality, segregation of the communications and noncommunications services would have to apply not only for accounting and billing purposes, but also to the allocation of capital and operating costs between the services for rate-making purposes. On the other hand, there is precedent in the transportation field to the effect that a common carrier may not engage in noncarrier business on a more favorable basis than carrier business by offsetting losses against carrier revenues. ${ }^{93}$ In addition, with respect to the computer hardware involved, there may be reasons of technological difficulty, impracticality, and cost for not effecting this separation. ${ }^{94}$

\section{Economic Policy: Natural Monopolies and Alternatives to Regulation}

Even though it may be shown that computer information services are valid subjects of FCC regulation under the terms of the Communications Act, the Commission is equally concerned with policy questions, the most important of which is whether the objectives of the Act will be better served by the development of a free competitive market or a regulated one. The answer to this question involves a consideration of the "natural monopoly" and "public utility" concepts, and a determination of the economic and social conditions that should be prerequisites to federal regulation.

Natural monopolies are exceptions to the generally competitive nature of the American economy. They are justified when necessary to secure vital national objectives, ${ }^{95}$ or when competition would produce inferior service and costly duplication of facilities in a field where there are no viable alternatives open to the consumer and the service

93 Southern Ry. v. United States, 186 F. Supp. 29, 37 (N.D. Ala. 1960), aff'd sib nom. Shaw Warehouse Co. v. Southern Ry., 294 F.2d 850 (5th Cir. 1961).

94 See text accompanying notes 4-11 supra.

95 Von Mehren, The Antitrust Laws and Regulated Industries: The Doctrine of Primary Jurisdiction, 67 HARv. L. REv. 929 (1954). 
itself is a virtual necessity like electricity, gas, or water. ${ }^{96}$ In the case of a natural monopoly, the alternatives available to the government are to instigate public ownership of the facilities or to develop schemes for public regulation.

Historically, the option of public regulation has been more often, relied upon ${ }^{97}$ and a case-by-case approach has been used to determine the need for regulation..$^{98}$ The difficulty with any broader approach is that once regulation has been instituted it is virtually impossible to redevelop a competitive market.99 Common regulatory methods include the imposition of special rules and regulations designed to prevent consumer exploitation and harmful competition. In addition, regulation may be accomplished by limiting the number of entities that may provide the service.

Natural monopolies are characterized by barriers to market entry such as the need for a high fixed capital investment, state franchise or licensing requirements, a limited source of supply, heavy constant costs, decreasing average costs, large plant size, centralization of supply, rigid price structures, a low risk factor, and an obligation to meet all demands for the service. ${ }^{100}$

Public utilities are natural monopolies said to be affected with the public interest. These industries are sometimes called "public service corporations" or "quasi-public corporations" to indicate that the public has a special interest in ensuring the performance of specific

\section{6}

[C]ompetition can assure protection of the public interest only in an industrial setting which is conducive to a free market and can have no place in industries which are monopolies because of public grant, the exigencies of nature, or legislative preference for a particular way of doing business.

Pennsylvania Water \& Power Co. v. FPC, 193 F.2d 230, 234 (D.C. Cir. 1951), aff'd, 343 U.S. 414 (1952). The concept of "natural monopoly" was expanded during the New Deal, and great stress was put on the public policy aspects of federal regulation with the result that many of the industries brought under regulation at that time have remained so, even though the concept itself may have been largely the creation of industrial propagandists. E. HAwley, The New DeAl aNd the Problem of MoNopoly 2 (1966). See B. Behling, Competition and Monopoly in Public UTiliti Industries (1938); Note, Is Regulation Necessary? California Air Transportation and National Policy, 74 YALE L.J. 1416 (1965).

97 Munn v. Illinois, 94 U.S. 113 (1877).

${ }^{98}$ See Schwartz, Legal Restriction of Competition in the Regulated Industries: An Abdication of Judicial Responsibility, 67 HARv. L. Rev. 437 (1954).

99 Friedman, Monopoly and the Social Responsibility of Business and Labor, in Monopoly Power and Economic Performance 109 (E. Mansfield ed. 1964).

100 Address by Bernard R. Strassburg, "The Marriage of Computers and Communications-Some Regulatory Implications," before the Association for Computing Machinery, Washington, D.C. Chapter, Oct. 20, 1966, at 3; see D. PARKHILL, ThE Challenge of the Computer UTimtTy 147 (1966). See also M. MAsser, Competition and Monopoly (1962); G. Stocking \& M. Watkins, Monopoly and Free ENTERPRISE (1951). 
services at reasonable prices. ${ }^{101}$ In specific circumstances, public carriers, stockyards, and water mills, as well as gas, water, and electricity suppliers have been considered public utilities. ${ }^{102}$

Historically, the traditional forms of communication have been regulated as public utilities possessing natural monopoly characteristics :

The history of the domestic telegraph industry . . . indicates that competition . . . has not had the expected and desired effects. Competitive practices have resulted in useless paralleling of facilities, duplication of operations, and wasteful expenditures of resources and manpower . . . . Moreover, telegraph services appear to fall within the field of "natural monopolies" such as the telephone, power and gas distribution utilities, where it has usually been found by experience that one company adequately regulated can be expected to render a superior service at lower cost than that provided by competing companies. ${ }^{103}$

Additionally, regulation of communications carriers has been justified on the ground that price competition would be destructive and result in economic waste.

Broadcasting is not a common carrier activity, ${ }^{104}$ although it is subject to licensing requirements based on the "public interest, convenience, and necessity . . . ."105

In contradistinction to communication by telephone and telegraph, which the Communications Act recognizes as a common carrier activity and regulates accordingly in

$101 \mathrm{~A}$ public utility has been described as a business that is

(1) affected with a public interest, and (2) bears an intimate connection with the processes of transportation and distribution, and (3) is under an obligation to afford its facilities to the public generally, upon demand, at fair and nondiscriminatory rates, and (4) enjoys in a large measure independence and freedom from economic competition brought about by the grant of a franchise from the state placing it in this position.

Davies Warehouse Co. v. Brown, 137 F.2d 201, 227 (Emer. Ct. App. 1943) (emphasis in original), rev'd on other grounds sub nom. Davies Warehouse Co. v. Bowles, 321 U.S. 144 (1944).

102 Terminal Taxicab Co. v. Kutz, 241 U.S. 252 (1916) (public carriers) ; Cotting v. Goddard, 183 U.S. 79 (1901) (stockyard) ; Head v. Amoskeag Mfg. Co., 113 U.S. 9 (1885) (water mill); Spring Valley Water Works v. Schottler, 110 U..S. 347 (1884) (gas and water). The common standard characterizes a public utility as "affected with the public interest," which means "no more than that an industry, for adequate reason, is subject to control for the public good." Nebbia v. New York, 291 U.S. 502, 536 (1933). See generally D. Parkhill, The Chatlenge of the Computer UtiltiY 147 (1966).

103 In re Western Union Telegraph Co., 10 F.C.C. 148, 162, modified, 25 F.C.C. 35 (1958).

104 Communications Act $\S 3(\mathrm{~h}), 47$ U.S.C. $\$ 153(\mathrm{~h})$ (1964).

10547 U.S.C. $\$ 309$ (a) (1964). 
analogy to the regulation of rail and other carriers by the Interstate Commerce Commission, the Act recognizes that broadcasters are not common carriers and are not to be dealt with as such. Thus the Act recognizes that the field of broadcasting is one of free competition. ${ }^{106}$

Apparently broadcasting was found not to embody the evils of wasteful, destructive competition and discriminatory rates that were feared from the transportation common carriers.

The extent to which the Communications Act requires that common carriers be protected from competitive harm is unclear. But it has been suggested that the "just and reasonable" standard ${ }^{107}$ applicable to the tariff provisions of common carriers does not permit as much "fostering of competition per se" 108 as the "public interest, convenience, and necessity" standard ${ }^{109}$ applicable to broadcasting..$^{110}$ This distinction may indicate the relative degrees of competitive freedom available under a system of tariff regulation and a licensing scheme.

Within the broad range of diverse computer information services, certain offerings more closely approximate natural monopolies than others. For example, it has been pointed out that a medical information network has analogies to a regional electric power system, ${ }^{111}$ and that a case-law data bank has monopolistic characteristics on even a national scale. ${ }^{112}$ But most computer information services do not satisfy the conditions for natural monopolies. Market entry is relatively easy, and a substantial number of varied firms, including computer manufacturers and service bureaus, have entered the field. ${ }^{113}$ Only a small initial outlay for hardware may be required under the rental plans that are available. ${ }^{114}$ Costs vary, depending on the expenses of research and development and the nature of the service that is to be provided. While costs may be decreased by sharing a com-

106 FCC v. Sanders Bros. Radio Station, 309 U.S. 470, 474 (1940).

10747 U.S.C. $\$ 201$ (b) (1964).

108 In re Allocation of Frequencies in the Bands Above $890 \mathrm{mc}, 18 \mathrm{P} \& \mathrm{~F}$ Rapro REG, 1767, 1788 (1960), quoted in Computer Services, supra note 3, at 335.

10947 U.S.C. $\$ 309$ (a) (1964).

110 Computer Services, supra note 3 , at 335.

111 Irwin, supra note 3, at 1313.

112 Id. 1317.

113 Id. 1300-02.

114 Irwin, The Computer Utility, Datamation, Nov. 1966, at 26-27. 
puter's memory capacity, the expense of communications lines, which varies with distance, may necessitate regional operations on a moderate scale. Given the expense of software and the technical limitations on memory capacity, ${ }^{115}$ even average costs may not decrease as production increases.

Since the rapid rate of technological change limits the useful life of a computer, ${ }^{118}$ computer information services have a higher risk than the usual public utility. There is constant pressure to revise and adjust existing services to conform to customer needs. Providing a multitude of services requires a flexibility of structure unlike that required for the limited services offered by public utilities. As a result there is arguably no feasible way to supply all reasonable service demands made by every customer, as there is with public utilities.

The availability of alternative services, which is determined by the demand for the services and the profit to be derived from furnishing them, indicates the competitive nature of the computer information industry. Public utilities provide necessities to the populace, but a computerized information service can hardly be considered a necessity. Stock market quotations, airline reservations, credit ratings, and marketing services have little similarity to vital commodities. In a natural monopoly, entrance into a market by an additional firm would simply redistribute existing business, but new market entries in the computer information field create new business, lower rates, and improved service-in short, a more competitive industry. Regulation could act as a barrier against innovation by standardizing the services and freezing their development.

115

The relationship of moderately high fixed costs and significant variable costs indicates that there is less significant economy of scale in a computer utility as compared with that of public utilities. Actually, the most efficient computer utility in the next few years may be the small, aggressive innovator with a small, hand-picked crew of specialists in a certain market segment.

C. Barnett, Jr., \& Assoctates, The Future of the Computer Utmity 87 (1967).

116

Public utilities in general are characterized by the presence of a very large and expensive physical plant with a much higher ratio of fixed capital to sales than is found in other industries. Capital turnover is consequently slow and is likely to take the form of a gradual evolutionary growth of the physical plant as receipts are converted into equipment. In view of these heavy capital costs, it is obviously desirable to obtain a long useful life from the utility plant, and indeed in the power and telephone industries at any rate, lives of many decades are common.

The computer public utility is also likely to be a rather large system requiring a heavy capital investment comparable to that found in the older utilities. However, ... the computer industry has been characterized, since its birth only two decades ago, by the presence of an unusually rapid rate of technological change.

D. Parkhill, The Challenge of the Computer Utility 143-44 (1966). 
It appears doubtful that computer information services meet the tests of natural monopolies or public utilities, and on the basis of these tests there should probably not be regulation at this time. ${ }^{117}$

It is possible that the Communication Satellite Corporation could fill the global need for computerized communication information services, ${ }^{118}$ and undercut regional development in a competitive market by satisfying the criteria for a natural monopoly through the use of a satellite system. ${ }^{119}$ However, the present limits of technology make this a rather remote possibility. It is also possible that the FCC will decide to approach Congress for a specific mandate regarding the control of computer information services. But it is unlikely that Congress would respond. ${ }^{120}$

From a theoretical point of view, regulation of computer information services could serve the public good by bringing order and predictability to the development of the industry. However, data processing coupled with message switching and incorporated within a computerized information system probably does not fall within the regulatory domain of the FCC, and probably is not subject to federal regulation under the tests of natural monopoly or public utility. In any attempt at regulation, fairness would require regulation of all entities furnishing similar services, and this might greatly overextend the Commission in the absence of additional regulatory powers or guidance from Congress. While it might be desirable to control the cost of leased communication lines in the short run, future technological development may drastically alter the circumstances upon which regulation is based. Optimum development of the computer information industry may eventually depend upon keeping the supply of communication circuits in line with computer expansion by exempting even message switching from regulation.

Several alternatives to regulation have been suggested to encourage and control the development of the computer information industry, including government ownership of a national information processing network, ${ }^{121}$ "reevaluation of communication tariffs and practices," 122

117 C. BARNeTT, JR., \& Associates, supra note 115, at 88; Irwin, supra note 3, at $1317-18$.

118 L. Early, Satellite Communications for the Computer Utility, Mar. 21, 1967, at 2 (unpublished manuscript presented at the U.C.L.A. Symposium on Computers). $110 \mathrm{Id}$. at 14.

120 Cf. C. Barnett, Jr., \& Associates, The Future of the Computer Utility $93(1966)$.

121 Irwin, supra note 3, at 1318-19; U.S. NAt'l CoMm'N on TEChNology, AutoMation and ECONOMIC Progress, TeChNology and the AMrRican ECONOMY 252 (1966), quoted in Irwin, supra note 3 , at 1318 n.41.

122 Irwin, supra note 3 , at 1319. 
and encouragement of new market entries in the communications field. ${ }^{123}$ A more effective alternative than these might be to expand reporting and disclosure requirements for the unregulated activities of communications common carriers. Complete disclosure should be sufficient to protect the public interest without complicating or unnecessarily hindering industry development. In addition, disclosure would permit positive steps to be taken if the unregulated development of computer information services resulted in abuses. But until that time, the question of federal regulation should be answered in the negative.

123 Irwin, supra note 3 , at $1319-20$. 